A N N A LE S

UNIVERSITATIS MARIAE CURIE-SKŁODOWSKA LUBLIN - POLONIA

VOL. XXIX, 4

SECTIO J

2016

Collegium Da Vinci w Poznaniu

KINGA MANN

mann.kinga@gmail.com

\title{
Wykorzystanie Analizy Transakcyjnej $w$ executive coachingu
}

The Use of Transactional Analysis in Executive Coaching

\section{STRESZCZENIE}

Artykuł dotyczy wykorzystania koncepcji Analizy Transakcyjnej w executive coachingu. Autorka głównie koncentruje się na omówieniu bazowych założeń pracy z klientem oraz prezentuje wybrane narzędzia wykorzystywane w executive coachingu. Jednym z ograniczeń w stosowaniu Analizy Transakcyjnej jest to, że nie ma ona jasnej i ustrukturyzowaneej metodologii prowadzenia sesji. Może zatem służyć jako wsparcie dla doświadczonych coachów, którzy potrzebują dodatkowych narzędzi, lecz ogranicza impakt, jaki może wnieść w całe środowisko coachingowe. W ostatniej części opracowania autorka prezentuje proponowany model prowadzenia procesu coachingowego w nurcie Analizy Transakcyjnej, który wypracowała przez lata praktyki w pracy z menedżerami i organizacjami.

Słowa kluczowe: executive coaching; Analiza Transakcyjna; coaching w Analizie Transakcyjnej; narzędzia w coachingu; struktura sesji coachingowej

\section{WPROWADZENIE}

Coaching stał się bardzo popularną metodą rozwoju potencjału pracowników w organizacjach. Szczególną jego formą jest executive coaching, który zajmuje się rozwojem liderów w organizacji. Istnieje wiele definicji executive coachingu (zob. m.in. Barnard 1938, Levinson 1996, Peterson 1996 za: Stokes, Jolly 2010 , 
s. 245-246; Kilburg 2002 za: Krausz 2005, s. 367), określanego również terminem leadership coaching (zob. Czarkowska [red.] 2013). Na potrzeby tego artykułu executive coaching definiować będziemy jako relację między klientem pełniącym rolę menedżerską (przede wszystkim na najwyższych poziomach władzy w organizacji) a coachem, której celem jest osiągnięcie wspólnie określonych celów, głównie związanych z pełnieniem przez klienta roli profesjonalnej, ale także z poczuciem osobistej satysfakcji przez zastosowanie różnego typu technik wspomagających wzrost autonomii rozumianej jako świadomość siebie i innych, spontaniczność w relacjach oraz zdolność do intymności. Taka definicja zawiera podstawowe założenia Analizy Transakcyjnej, które zostaną omówione w niniejszym opracowaniu.

Analiza Transakcyjna (AT) została stworzona przez E. Berne'a w latach 50. XX w. i w pierwotnym zamyśle dedykowana była głównie psychoterapii. W 1963 r. Berne opublikował książkę, która odnosiła się do dynamiki grup i organizacji (Berne, 1966) i dała początek rozwojowi metodologii pracy w innych obszarach, m.in. edukacji i biznesie. Coaching jako metoda ma jednak w AT bardzo krótkie tradycje i nie doczekał się jeszcze jasnej, systematycznie opisanej metodologii (zob. Newton, Napper 2010, s. 184), która pozwalałaby na uporządkowanie procesu realizacji sesji coachingowych. Celem tego artykułu jest przybliżenie koncepcji Analizy Transakcyjnej, narzędzi ułatwiających pracę z klientem $\mathrm{w}$ executive coachingu oraz zaproponowanie własnej metodologii prowadzenia sesji coachingowych w oparciu o teorię AT i doświadczenie praktyczne autorki.

\section{PODSTAWOWE ZAŁOŻENIA DOTYCZĄCE PRACY Z KLIENTEM}

Analiza Transakcyjna opiera się na trzech podstawowych założeniach filozoficznych dotyczących ludzi (zob. Stewart, Joines 2016, s. 8; Newton, Napper 2010, s. 173; Stewart 2007, s. 3):

1. Ludzie są OK - co oznacza, że każdy człowiek ma swoją wartość i godność. To założenie odnosi się zarówno do innych, jak i do siebie (Ja jestem $\mathrm{OK}$ - Ty jesteś $\mathrm{OK}$ ).

2. Ludzie potrafią myśleć samodzielnie - zakłada, że każdy z nas jest zdolny do podejmowania samodzielnych decyzji, generowania rozwiązań i wybierania najlepszych dla siebie opcji.

3. Ludzie podejmują decyzje dotyczące swojego życia i te decyzje można zmienić - presupozycją jest tutaj przesłanie dotyczące tego, że jednostka może się zmienić, jeśli tylko zdecyduje, że tego właśnie chce. Zmiana wymaga podjęcia decyzji. 
Każde z tych założeń wpisuje się w filozoficzne ramy odniesienia do innych nurtów w coachingu ${ }^{1}$. $Z$ tej filozofii wprost wyłaniają się dwa założenia, które odnoszą się do praktyki AT: kontraktowanie oraz otwarta komunikacja. Otwarta komunikacja dotyczy nie tylko jasnego informowania klienta o procesie wspólnej pracy, z otwartą wymianą spostrzeżeń, możliwością wglądu w notatki, ale przede wszystkim do edukowania klienta w zakresie wiedzy z AT, odrzucenia żargonu psychologicznego ${ }^{2}$ i (zgodnie z założeniem OK - OK) zachęcania klienta do analizy własnego zachowania za pomocą poznanych narzędzi. Kontraktowanie zostanie omówione w dalszej części artykułu. Ważne jest podkreślenie, że oba elementy są jednymi ze składowych budowania obustronnego zaufania, bez którego niemożliwa staje się efektywna praca z klientem.

Berne w swoich pracach (Stewart 2007) podkreślał wykorzystanie tzw. myślenia marsjańskiego (Berne 2007, s. 126), które odnosi się do świadomej analizy zarówno treści, jak i procesu komunikacji i jest kluczową umiejętnością w pracy z klientami. Coach powinien zachowywać się jak Marsjanin, który po raz pierwszy odwiedza planetę Ziemię i nie zna panujących na niej zasad. Zamiast tego przysłuchuje się i obserwuje, bez nadawania znaczeń. Praktyczne doświadczenia autorki pokazują, że często ważnym determinantem w relacji coachingowej są pierwsze słowa klienta (np. „Nie wiem, czy poradzi sobie Pani z tak trudnym przypadkiem”, „Polecono mi Panią, bo podobno jest Pani najlepsza”, „Nie wiem, czy mój problem jest możliwy do rozwiązania" itd.). Zgodnie z teorią każde słowo, zdanie, zachowanie czy określona ich konstelacja odsłania coachowi elementy związane ze skryptem ${ }^{3}$ klienta, może stanowić zaproszenie do gry psychologicznej, odsłania nierozpoznania, ramy odniesienia itd. Zadaniem coacha jest uważne słuchanie i obserwowanie klienta, który najwięcej przekazuje, nie mówiąc wprost. Wyzwanie to odnosi się do rozróżnienia komunikacji na poziomie społecznym (jawnym) i psychologicznym (ukrytym), o których mówi Berne, opisując rodzaje transakcji (komunikatów) międzyludzkich4.

${ }^{1}$ Zob. np. założenia szkoły Ericksonowskiej: 1. Ludzie są OK tacy, jacy są, 2. Mają w sobie wszystkie potrzebne im zasoby, 3. Zawsze dokonują najlepszego wyboru w danym momencie, 4. Każdemu zachowaniu towarzyszy pozytywna intencja, 5. Zmiana jest nieuchronna (Atkinson, Chois 2009, s. 108-116).

${ }^{2}$ Berne, konstruując swoją teorię, zakładał przede wszystkim posługiwanie się przez praktyków AT językiem zrozumiałym dla laika. Związane jest to przede wszystkim z budowaniem partnerskiej relacji z klientem oraz zachęcaniem go do do uzyskania autonomii. Niestety, założenie to implikuje trudności związane z rozwojem i stosowaniem samej teorii, która bywa odbierana jako zbyt prosta i nieprzystająca do hermetycznego języka psychoterapii (zob. Steward 1992 za: Newton, Napper 2010, s. 184).

${ }^{3}$ Skrypt odnosi się do podjętych w dzieciństwie decyzji związanych z tym, jak będzie wyglądało całe nasze życie (za: Stewart 2007, s. 22), a potem jest odtwarzany przez nas w dorosłości.

${ }^{4}$ Berne (2012, s. 21-25; por. Berne 2008, s. 90-96) wyróżnia transakcje komplementarne, skrzyżowane, proste i ukryte (a te z kolei dzielą się na kątowe i podwójne). 
Celem pracy z klientem według Analizy Transakcyjnej jest osiągnięcie przez niego autonomii ${ }^{5}$, która zdaniem Berne'a (2012, s. 149; zob. Steiner 1990) „ujawnia się przez wyzwolenie czy też odzyskanie trzech zdolności: świadomości, spontaniczności oraz intymności”. Ważne jest to, jak autor definiuje te trzy pojęcia, aby koniecznie rozróżnić je od ich potocznego rozumienia, które mogłoby wprowadzać niepotrzebną konfuzję wśród teoretyków, praktyków, ale przede wszystkim samych klientów. Pierwszym z pojęć, które w szczególności wymaga zdefiniowania, jest intymnośćc. Intymność dla Berne'a jest tożsama $\mathrm{z}$ funkcją Dziecka Naturalnego, która wyraża się w wolnej od gier relacji z innymi, zakłada czystość intencji i autentyczność. W odniesieniu do lidera można mówić o autentycznym przywództwie ${ }^{7}$ lub autentyczności, spójności w wyrażaniu siebie w kontekście przewodzenia innym. Autentyczność natomiast wymaga dużej świadomości zarówno siebie, jak i innych. Ś wiad omość związana jest z odbieraniem świata takim, jakim jest, bez filtrów, interpretacji, otwarciem na doznania zmysłowe, kontakt z bodźcami z wewnętrznego i zewnętrznego świata klienta ${ }^{8}$. Ostatnim elementem wymagającym zdefiniowania jest spontaniczność, która jest rozumiana w tym ujęciu jako „wybór, wolność wyboru i wyrażania własnych uczuć z dostępnego asortymentu (uczucia Rodzica, uczucia Dorosłego i uczucia Dziecka)" (Berne 2012, s. 151).

Rolą coacha w executive coachingu jest towarzyszenie klientowi w drodze do osiągnięcia autonomii. Aby cały proces mógł zakończyć się sukcesem, bardzo ważne jest zbudowanie z klientem relacji opartej na zaufaniu. W procesie tym szczególnie istotną rolę spełniają: przyzwolenie, ochrona i moc (Crossman 1966 za: Stewart 2007; zob. Krausz 2005), które odnoszą się bezpośrednio do myślenia, odczuwania, działania, ale przede wszystkim do osiągania sukcesu. Przyzwolenie jest modelowane przez coacha przez wykorzystanie otwartej komunikacji, odzwierciedlanie i docieranie do rzeczywistych zasobów klienta oraz odkrywanie opcji, które posiada. Przyzwolenie to przyznanie klientowi pełnej akceptacji do

\footnotetext{
${ }^{5}$ Berne nigdy nie podał definicji autonomii, implicite sugerował jednak, że jest to „wolność od skryptu”. Stewart i Joines (2016, s. 364) podają następującą definicję autonomii: „(...) jest to zachowanie, myślenie lub odczuwanie będące reakcją na rzeczywistość tu i teraz, a nie na przekonania skryptowe”. Hay (2012, s. 16) podaje definicję autonomii wyrażającą się w czterech kompetencjach: świadomości, posiadaniu alternatyw, autentyczności oraz przywiązaniu.

${ }^{6}$ Intymność w definicji Stownika Języka Polskiego PWN jest definiowana jako „bardzo osobisty charakter czegoś”, „,erotyczny, miłosny charakter czegoś”, „sprawa osobista, często o charakterze erotycznym”. Władysław Kopaliński (1989) rozważa słowo „intymny” jako: „ściśle osobisty, poufny, sekretny, bliski, zażyły”, z łac. intimus (tłum. autora: ,wewnętrzny”).

${ }^{7}$ Po raz pierwszy o autentycznym przywództwie pisał Bill George w książce Authentic Leadership: Rediscovering the Secrets to Creating Lasting Value (2003) (za: George 2007).

${ }^{8}$ Tak rozumiana świadomość jest bliska nurtowi Mindfulness Based Stress Reduction (MBSR), ale należy pamiętać, że nie jest z nim tożsama.
} 
eksperymentowania i uczenia się nowych zachowań, sposobu myślenia, odczuwania. Ochrona dotyczy stworzenia odpowiednich warunków do eksperymentowania z nowymi formami zachowania, myślenia czy odczuwania, aby w efekcie klient mógł doświadczyć sukcesu. Ochrona jest związana z ekologią rozwiązań, które wypracowuje klient, ale też ze sprawdzeniem, jak wpłyną na cały jego system. Ważnym aspektem w zakresie dawania ochrony jest uważność coacha skierowana na to, aby sam nie przekroczył cienkiej granicy między ochroną a ratowaniem 9 , które może prowadzić do gier psychologicznych, wzmocnić relację symbiotyczną, a co za tym idzie skrypt klienta. Moc będzie tutaj rozumiana jako zasoby własne coacha, osadzenie w roli, które wyraża się przez to, że coach dokładnie wie, co i dlaczego robi, podejmując konkretne interwencje $\mathrm{w}$ relacji z klientem. Dzięki temu klient zyskuje poczucie bezpieczeństwa. Z drugiej strony odnosi się do „odzyskiwania mocy” przez klienta poprzez świadome decyzje, które podejmuje oraz zasoby, których używa do realizacji wybranych opcji, aż po efekty swoich działań.

Jak konkluduje Krausz (2005, s. 369-370): ,Jedną z funkcji executive coachingu jest dostarczanie ochrony bez nadopiekuńczości (overprotection) oraz przyzwolenia bez pobłażliwości (permissiveness), aby coachee mógł nauczyć się myśleć, czuć, działać i odnosić sukces w granicach etyki oraz odpowiedzialności”.

\section{NARZĘDZIA W COACHINGU}

Analiza Transakcyjna jest teorią kontraktową (Stewart 2000, s. 14-15), co oznacza, że nie można mówić o coachingu czy jakiejkolwiek innej formie pracy z klientami, w którym nie byłoby dobrze zdefiniowanego kontraktu między stronami. Berne definiuje kontrakt jako ,jednoznaczne, dwustronne zobowiązanie dotyczące dokładnie zdefiniowanego toku działań” (Berne 1966, s. 362) i rozróżnia trzy poziomy kontraktu:

1. Administracyjny ${ }^{10}$, który $\mathrm{w}$ przypadku executive coachingu dotyczy określenia czasu, miejsca, długości trwania sesji, wysokości i sposobu płatności, liczby spotkań, możliwości odwołania sesji itd.

2. Profesjonalny, który odnosi się do określonego celu klienta, jasno zdefiniowanych granic coachingu ${ }^{11}$ oraz kompetencji coacha. Dobrze, aby cele na tym poziomie były sformułowane w sposób zrozumiały dla obu

\footnotetext{
${ }^{9}$ Ratowanie odnosi się do zaburzenia relacji OK - OK oraz nierozpoznawania możliwości i zasobów klienta do samodzielnego poradzenia sobie z daną sytuacją.

${ }^{10}$ Hay (2010) nazywa go kontraktem proceduralnym, a Krausz (2005, s. 368) - biznesowym.

${ }^{11}$ Granice coachingu odnoszą się do jasnego określenia, czym on jest, w jakim nurcie, na jakich zasadach i zgodnie z jakim kodeksem etycznym pracuje coach oraz tego, kiedy kończy się coaching, a zaczynają się inne formy wsparcia (terapia, szkolenie itd.).
} 
stron, możliwe do osiągnięcia oraz mierzalne (odnoszące się do obserwowalnych efektów) $)^{12}$.

3. Psychologiczny, będący najtrudniejszym elementem całego procesu kontraktowania, ponieważ obejmuje ukryte i niewyrażone, a często nawet nieuświadomione, motywy kierujące zarówno coachem, jak i coachee. Poziom ten dotyczy potrzeb i oczekiwań obu stron oraz wzorców zachowań, które wynikają bezpośrednio ze skryptu i mogą prowadzić do sabotażu poprzednich poziomów. Ważne jest zatem, aby coach pozostawał pod stałą superwizją ${ }^{13}$.

Stainer (1990, s. 243-250; por. Stewart 2000, s. 15) podkreśla, że w Analizie Transakcyjnej kontrakty są najważniejszą częścią całego procesu i powinny być traktowane z takim samym poszanowaniem, jak kontrakty prawne. Aby stało się to możliwe, powinny one spełniać następujące wymagania:

1. Wynikać z obopólnej zgody dwóch stron.

2. Wiązać się z ustalonymi świadczeniami (wzajemnymi korzyściami dla obu stron).

3. Obie strony powinny posiadać odpowiednie kompetencje do zawarcia kontraktu i wykonania jego postanowień.

4. Cel kontraktu jest zgodny z prawem.

Kontrakty zawierane w executive coachingu rzadko są kontraktami dwustronnymi (coach - coachee), zdecydowanie częściej są to kontrakty trójstronne (English 1975), a nawet wielostronne (Hay 2007). W tych przypadkach coach powinien zadbać o transparentność kontraktu dla wszystkich zaangażowanych stron. Wartość takiego działania wyraża się w zachowaniu odpowiednich dystansów psychologicznych (Micholt 1992) ${ }^{14}$.

W przypadku coachingu autorka niniejszego artykułu rozróżnia dwa rodzaje kontraktów: kontrakt na proces oraz kontrakt na sesję. Kontrakt na proces dotyczy kontraktu zawieranego jeszcze przed rozpoczęciem sesji coachingowych. Zazwyczaj kontrakt ten jest spisywany w formie umowy prawnej, która chro-

${ }^{12}$ Stewart (2007, s. 123) podaje sześć pytań dla efektywnego kontraktu: 1. Czy kontrakt jest realny/możliwy do wykonania?, 2. Czy jest bezpieczny?, 3. Czy został sformułowany pozytywnie?, 4. Czy jest obserwowalny?, 5. Czy został umieszczony w jasnym kontekście?, 6. Czy zakłada ruch klienta w stronę autonomii?

${ }^{13}$ Superwizja pozwala coachowi uwrażliwić się na mogący wystąpić w relacji z klientem proces równoległy, który jest definiowany jako proces występujący między coachem a klientem, odzwierciedlający się w relacji coach - superwizor (zob. Searls 1955 za: Watkins 2016, s. 1; Hay 2007, s. 41). Pierwotnie proces równoległy odnosił się do relacji superwizyjnej w psychoterapii (por. Cassoni 2007). Superwizja pozwala zidentyfikować mogące pojawić się gry jako destrukcyjny sposób na dostarczanie znaków rozpoznania, ale przede wszystkim pozwala coachowi kontrolować jego wewnętrzną dynamikę, która może wpływać na jego efektywność.

${ }^{14}$ Autorka koncepcji definiuje dystans psychologiczny jako spostrzeganą bliskość albo dystans w relacjach między trzema stronami kontraktu (Micholt 1992, s. 228). 
ni wszystkie strony przed możliwymi trudnościami. Zazwyczaj taki kontrakt jest ustalany podczas więcej niż jednego kontaktu czy spotkania z klientem. Obejmuje omówienie wszystkich poziomów kontraktu wyróżnionych przez Berne'a oraz uwzględnia wszystkie strony, zgodnie z sugestią English (1975), Hay (2007) oraz Micholt (1992). Kontrakt na sesję jest związany z ustaleniem mniejszego celu, który będzie realizowany w ramach jednej sesji z klientem. Pozwala to przełożyć główny i długofalowy cel z kontraktu na proces, na mniejsze cele, łatwiejsze do zrealizowania i przynoszące szybsze efekty.

Warto zwrócić uwagę również na fakt, że cele ustalane w kontrakcie mogą ulegać zmianie w miarę postępów czynionych przez klienta. Często okazuje się, że cel zgłoszony przez niego na pierwszym spotkaniu, zostaje przeformułowany na trzecim albo którymś $\mathrm{z}$ kolejnych. Jest to naturalny proces w coachingu.

Konkludując powyższe rozważania, podczas ustalania kontraktu na proces należy wziąć pod uwagę fakt, że cel może się zmieniać w czasie i w związku z tym warto, aby coach zabezpieczył możliwość elastycznej zmiany wcześniejszych zapisów, szczególnie w kontekście zawartej umowy prawnej.

Kontrakty chronią relację coachingową przed pojawianiem się w niej gier psychologicznych. Zgodnie z definicją Berne'a (2012, s. 37) „grą nazywamy serię komplementarnych transakcji ukrytych, prowadzących do dobrze określonego, dającego się przewidzieć wyniku". Gry są zawsze nieświadome i rozgrywają się między minimum dwiema osobami. Głównym celem gier jest uzyskanie znaków rozpoznania ${ }^{15}$, których jednostka nie może uzyskać przez intymność, której nie potrafi osiągnąć, ponieważ nie została tego nauczona albo doświadczyła źle pojętej intymności w formie nadużycia i w związku z tym gra ma dla niej charakter pozornie „chroniący”" ${ }^{\prime 16}$ Gry służą też potwierdzeniu przekonań skryptowych (, Jestem beznadziejna”, „Ludziom nie można ufać”, „Nikomu z mojej rodziny nigdy nie udało się tego osiągnąc i na mnie ciąży ta klątwa") i są związane z przeżywaniem skryptowych emocji (np. odrzucenia, poczucia winy, poczucia krzywdy itd.). Wszystko to wzmacnia utarte wzorce zachowań, które jednostka powiela

${ }^{15}$ Znaki rozpoznania (inaczej „głaski”) są terminem wprowadzonym przez Berne’a (2012) i odnoszą się do „podstawowej jednostki funkcjonowania społecznego” (Berne 2012, s. 9). Berne za Spitzem wnioskuje, że podstawową potrzebą ludzką, która pozwala nam pozostać we względnym zdrowiu psychicznym i fizycznym, jest potrzeba znaków rozpoznania (Berne 2012, s. 7-8). Wyróżnia się następujące rodzaje znaków rozpoznania: werbalne i niewerbalne, pozytywne i negatywne oraz warunkowe i bezwarunkowe (za: Stewart, Joines 2016, s. 97). Znaki rozpoznania odnoszą się do pobudzania motywacji klienta przez wzmacnianie jednych i wygaszanie innych rodzajów zachowań (por. Hay 2012, s. 34-37).

${ }^{16}$ Zachowania z pozoru dysfunkcyjne mogą spełniać konkretne funkcje. Ciekawy przykład analizy dysfunkcyjnego zachowania opisuje w swoim artykule Kahn (2012), omawiając radzenie sobie pracowników socjalnych z brakiem możliwości wyrażenia złości w stosunku do swoich klientów, co powoduje, że napięcie jest przenoszone na relacje w organizacji. Szkodzi to organizacji, ale pomaga jednostkom. 
w ciągu swojego życia, oczekując za każdym razem innych efektów. Zidentyfikowanie przez coacha gier, w które może grać z klientami, wpływa na efektywność jego pracy, ale przede wszystkim daje większą szansę na przeprowadzenie procesu coachingu w taki sposób, aby klient mógł nauczyć się nowych, konstruktywnych form zachowania. Taka refleksja ze strony coacha jest bardzo potrzebna, ponieważ najczęściej klienci wybierają coachów, w relacji z którymi wzrasta podobieństwo zagrania w ich ,ulubione” gry.

Analiza gier może posłużyć również do zrozumienia tego, w jakie gry gra nasz klient $\mathrm{w}$ organizacji. Mogą one zostać zidentyfikowane przez poszukiwanie powtarzalnych wzorców zachowań. Jeśli klient mówi: „Dlaczego zawsze mnie się to przytrafia?", może to być sygnał, że właśnie rozegrała się gra. Prześledzenie sekwencji transakcji, zachowań między wszystkimi uczestnikami, analiza towarzyszących temu emocji i myśli i wreszcie dotarcie do ukrytych, niezaspokojonych potrzeb klienta, może pozwolić na zrozumienie wzorca i pomóc klientowi w przyszłości. Pomocne w tym mogą okazać się przygotowane przez Jamesa (1973, s. 15) pytania, które służą zidentyfikowaniu planu gry:

1. Co przydarza Ci się ciągle? (Jakie sytuacje się powtarzają?)

2. Jak to się zaczyna? (Od czego się zaczyna? Jaki jest początek?)

3. Co dzieje się później? (Jaki jest następny krok?)

4. Jak to się kończy?

5. Jak się czujesz, kiedy to się kończy?

Innym narzędziem analizy dynamiki gier psychologicznych jest trójkąt dramatyczny Karpmana (1968 za: Stewart, Joines 2016; zob. Hay 2010, 2007; Choy 1990). Karpman wyróżnił trzy główne postaci w grach: Ratownika, Ofiarę i Prześladowcę. Gra rozpoczyna się w momencie, kiedy u jednostki występuje nierozpoznanie. W przypadku roli Ratownika nierozpoznanie dotyczy możliwości osoby, będącej w roli Ofiary, związanych z samodzielnym rozwiązaniem problemu, dlatego właśnie przejmuje za nią odpowiedzialność. W tak zaprojektowanej relacji zaburzona zostaje pozycja OK - OK i pojawia się przekonanie „Ja jestem OK - Ty nie jesteś OK i dlatego muszę Cię ratować”. Wzmacnia to zwrotnie przekonanie osoby będącej w roli Ofiary o tym, że nie potrafi sama zadbać o siebie i rozwiązać problemów, które posiada (,Ja nie jestem OK - Ty jesteś OK, dlatego właśnie Ty możesz mi pomóc, bo sama sobie nie poradzę"). W przypadku roli Prześladowcy nierozpoznanie dotyczy znaczenia osoby pozostającej w roli Ofiary, która nie jest dla niego ważna albo też przejmuje wobec niej tryb odwetowy, zakładając, że „mogę być OK, tylko jeśli Ty zostaniesz ukarana" (Choy 1990, s. 41). Nie rozpoznaje zatem innych opcji rozwiązania, innych możliwości zachowania w danej sytuacji, jak tylko prześladowanie albo odrzucenie. Gra, zgodnie z założeniem Karpmana, trwa przez wymianę transakcji komplementarnych i postępuje przez „przełączenie” (switch) między 
rolami. Ostatecznie każdy z graczy kończy z negatywnymi emocjami i potwierdzeniem własnych przekonań, co jest nazywane „wypłatą w grze”.

Choy proponuje wykorzystanie trójkąta mocy jako narzędzia eliminującego nierozpoznania (Choy 1990, s. 42). Koncentruje się on na wykorzystaniu pozytywnych aspektów każdej roli. Osoba, która najczęściej w grze przyjmuje rolę Ratownika, posiada olbrzymie pokłady opiekuńczości. Aby mogła w pełni wykorzystać swój potencjał, warto, by nauczyła się również lepiej słuchać innych i samej siebie w zakresie tego, co rzeczywiście jest potrzebne i czego chce każda ze stron. Osoby mające tendencję do wchodzenia w rolę Ofiary mają natomiast olbrzymie pokłady wrażliwości (vulnerable). Powinny one popracować nad swoimi umiejętnościami związanymi z rozwiązywaniem problemów i braniem odpowiedzialności oraz nad samoświadomością, szczególnie w zakresie własnych zasobów. Osoby najczęściej przyjmujące rolę Prześladowcy posiadają dobrze rozwiniętą asertywność w zakresie obrony własnych granic, ale powinny jeszcze popracować nad możliwościami realizacji swoich potrzeb, bez konieczności przekraczania granic innych osób.

Berne (1966 za: Krausz 2005) omawia osiem kategorii terapeutycznych interwencji (które nazywa operacjami terapeutycznymi - therapeutic operations). Nie wszystkie mogą zostać wykorzystane w niedyrektywnym podejściu coachingowym w pracy z menedżerami, ale dwa z nich dobrze sprawdzają się w tego typu relacjach. Są to: wywiad ${ }^{17}$ oraz informacja zwrotna ${ }^{18}$.

Wywiad oznacza „pytanie zaprojektowane dla udokumentowania klinicznie ważnej porcji informacji” (Krausz 2005, s. 371). Odnosi się on do zadawania pytań, których celem jest pobudzenie refleksji klienta. Umiejętności coacha w zakresie zadawania pytań będą miały decydujące znaczenie w przebiegu sesji i osiągnięciu przez klienta celów rozwojowych.

Informacja zwrotna, zgodnie z definicją Berne'a (Krausz 2005), polega na „użyciu informacji, które mają na celu zmieszanie pacjenta przez wskazanie mu niezgodności”. Coach, używając tej interwencji, odnosi się do prezentowanych przez klienta sprzecznych informacji i zachowań lub niespójności między komunikacją werbalną a niewerbalną. Ponieważ taka forma interwencji może być zagrażająca dla klienta, jeśli zostanie wprowadzona w nieumiejętny sposób, warto, aby coach zadbał o zakontraktowanie jej wcześniej oraz o wykorzystanie w momencie, kiedy relacja między nim a coachee będzie zbudowana na solidnych fundamentach zaufania.

${ }^{17} \mathrm{~W}$ oryginale interrogation, co w dosłownym thumaczeniu oznacza przesłuchanie. Z uwagi na mocno pejoratywny wydźwięk autorka zdecydowała się użyć słowa „wywiad”.

${ }^{18} \mathrm{~W}$ oryginale confrontation, co w tłumaczeniu oznacza konfrontację i znów niesie ze sobą negatywną konotację. Autorka także w tym przypadku zdecydowała się na użycie synonimu, który zdecydowanie lepiej odnosi się do tego, czego dotyczy dana interwencja. 
Głównym modelem, który autorka wykorzystuje w executive coachingu, jest matryca nierozpoznań (Mellor, Schiff 1975), a dokładniej uproszczona jej forma zaproponowana przez Hay $(2007,2010)$.

Mellor i Schift (1975, s. 295) definiują nierozpoznania (discounting) w następujący sposób: „(...) osoba, która jest w nierozpoznaniu, wierzy albo zachowuje się tak, jak gdyby pewne aspekty siebie, innych ludzi albo sytuacji posiadały mniejszą wartość (znaczenie) niż jest to w rzeczywistości”. Celem nierozpoznań jest utrzymywanie stałych ram odniesienia, dzięki którym jednostka może wzmacniać swój skrypt, dopasowywać świat do własnych przekonań. Nierozpoznaniom towarzyszy wyolbrzymienie, które odnosi się do przerysowania jakiegoś aspektu rzeczywistości i minimalizowania czy niezauważania innych.

Nierozpoznania można diagnozować przez pojawienie się czterech rodzajów zachowań pasywnych u klientów (Stewart, Joines 2016, s. 242):

1. Nierobienie niczego - w obliczu problemu jednostka przestaje działać, nie dąży do rozwiązania. Takie zachowanie wynika z nierozpoznania własnych możliwości i zasobów. W przypadku menedżera może objawiać się niereagowaniem na pojawiające się sytuacje trudne, niepodejmowaniem decyzji w sprawach ważnych, niereagowaniem na konflikty pojawiające się w zespole. Przyczyną jest najczęściej przekonanie, że nie ma wystarczających umiejętności, aby to zrobić dobrze.

2. Nadadaptacja - jest właściwa dla jednostek, które nadmiernie przystosowują się do sytuacji przez robienie więcej, niż się od nich oczekuje. W przypadku menedżera może to być niedelegowanie zadań i wykonywanie wszystkiego samemu. Jest to również przyjmowanie nierealistycznych celów od swoich przełożonych. Nierozpoznanie w tym przypadku nadal dotyczy zasobów jednostki, która nie ocenia ich zgodnie z rzeczywistością i przez to je przeszacowuje, dostosowuje możliwości do wyimaginowanych oczekiwań innych osób.

3. Pobudzenie - charakteryzuje jednostki, które nie rozpoznają własnych możliwości działania w danej sytuacji. Zamiast rozwiązać problem, angażują się w czynności zastępcze, które w żaden sposób nie pomagają w danej sytuacji, a czasem nawet mogą jej zaszkodzić. W przypadku menedżera może to być poświęcanie czasu na układanie dokumentów według dat, podczas kiedy otrzymał nierealne do wykonania cele. Innymi zachowaniami zastępczymi są: kompulsywne jedzenie, ćwiczenie, obgryzanie paznokci, gryzienie długopisów, przebieranie nogami itd.

4. Samoutrudnienie lub przemoc - samoutrudnienie może (i często tak jest) przyjmować formę dolegliwości psychosomatycznych, ale może również przejawiać się w innych zachowaniach, których celem jest sabotowanie rozwiązania pojawiającego się problemu. Przykładem samo- 
utrudnienia w przypadku menedżera może być np. sytuacja, w której ma do zrealizowania bardzo wysokie plany sprzedażowe wraz ze swoim zespołem i nagle zaczyna poważnie chorować albo zapomina wysłać przygotowaną ofertę dla kluczowego klienta. Przemoc natomiast związana jest $\mathrm{z}$ mechanizmem przeniesionej agresji i u menedżera może wyrażać się agresywnymi zachowaniami w stosunku do swoich podwładnych, którzy nie są w stanie wykonać narzuconych im zbyt wysokich celów sprzedażowych.

Tworząc matrycę nierozpoznań, Mellor i Schiff (1975) określili trzy główne kategorie, według których są klasyfikowane nierozpoznania:

1. Obszaru (ja, inni, sytuacja) - odnosi się do sytuacji, w której jednostka nie rozpoznaje własnych możliwości, możliwości innych albo elementów sytuacji, które pozwoliłyby jej na rozwiązanie zaistniałego problemu.

2. Typu (bodziec, problem, możliwości) - jednostka nie zauważa bodźca, problemu albo możliwości działania w danej sytuacji.

3. Poziomu (istnienie, znaczenie, możliwość zmiany, zdolności osoby) jednostka może nie zauważać istnienia bodźca, problemu lub możliwości rozwiązania; może również nie zauważać ich znaczenia, możliwości zmiany albo zdolności własnych lub innej osoby do rozwiązania sytuacji.

Matryca nierozpoznań została stworzona na potrzeby psychoterapii. Ze względu na to, że w większości odnosi się do rozwiązywania problemów, może okazać się mało skuteczna w pracy z menedżerami nad rozwijaniem ich potencjału. Używanie matrycy nierozpoznań w jej klinicznym wydaniu może zatem budzić pewne kontrowersje, zwłaszcza że coaching jest rozpatrywany w kategoriach rozwojowych, a nie klinicznych. W związku z ograniczeniami wynikającymi z możliwości zastosowania omawianego modelu Hay $(2007,2010,2012)$ zaproponowała uproszczony model dedykowany pracy rozwojowej - schody do sukcesu (rys. 1).

Pierwszy poziom schodów do sukcesu odnosi się do nierozpoznania na poziomie sytuacji, co jest najpoważniejszą formą nierozpoznania. W przypadku menedżera może być tak, że nie zauważa on, że jest agresywny w stosunku do swojego zespołu i jakoś to wpływa na jego podwładnych, a efektem jego działań jest wysoka rotacja pracowników. Klient, który samodzielnie zgłasza chęć uczestniczenia w coachingu, zwykle ma świadomość sytuacji, w której się znajduje i rozumie, jakie znaczenie ma ta sytuacja w kontekście jego efektywności czy poczucia satysfakcji. Najczęściej impas następuje w momencie generowania i wdrażania rozwiązań. Zadaniem coacha jest (za pomocą pytań) przejście wraz z klientem przez wszystkie kroki.

Podsumowując, Analiza Transakcyjna dostarcza wielu użytecznych narzędzi i modeli, które mogą pomóc coachowi w skutecznym prowadzeniu procesów 


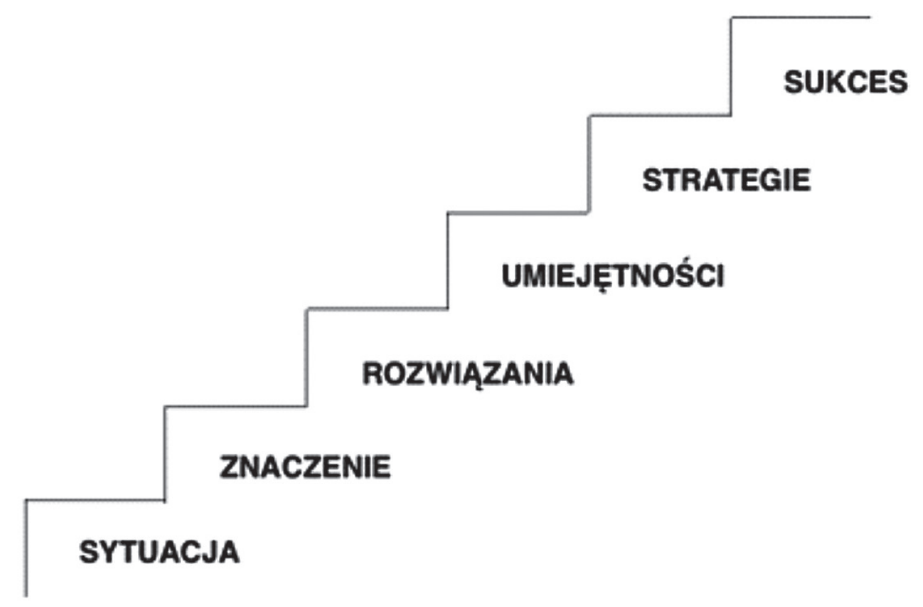

Rys. 1. Schody do sukcesu

Źródło: (Hay 2007, s. 35).

coachingowych z menedżerami. Mocną stroną teorii jest to, że koncentruje coacha na procesie prowadzenia sesji. Szczególną wagę przypisuje dobrej analizie psychologicznej sytuacji klienta, coacha oraz relacji między nimi. Jednym z kluczowych ograniczeń jest natomiast brak jasnej struktury prowadzenia sesji.

\section{MODEL PROWADZENIA SESJI COACHINGOWEJ WEDEUG AT}

Bazując na swoich praktycznych doświadczeniach oraz wiedzy z zakresu AT w coachingu, autorka stworzyła propozycję metodologii prowadzenia sesji coachingowej.

Pierwszym krokiem w procesie coachingu, zgodnie $\mathrm{z}$ wymogami teorii, jest określenie kontraktu na proces. Zwykle odbywa się to podczas tzw. sesji zerowej, której celem jest dookreślenie celów klienta, jego oczekiwań, motywów, potrzeb, ale również sprawdzenie tego, czy relacja z tym konkretnym coachem spełni jego oczekiwania. W przypadku executive coachingu zazwyczaj sponsorem jest organizacja i zwykle jej przedstawiciel (najczęściej HR) kontaktuje się z coachem, aby ustalić termin spotkania, w trakcie którego przedstawia cele i oczekiwania organizacji. Kolejne spotkanie odbywa się z beneficjentem ${ }^{19}$, aby ostatnie mogło odbyć się między wszystkimi zaangażowanymi stronami. Na tym właśnie spotkaniu są ustalane ostateczne cele, oczekiwania stron i efekty działań (kontrakt na poziomie profesjonalnym), jak również elementy związane m.in. z płatnościami, liczbą spotkań (poziom administracyjny) oraz zasady poufności związane z treścią sesji

${ }^{19}$ Zdaniem autorki jest to ważny moment, ponieważ pozostawia klientowi decyzję, czy właśnie $\mathrm{z}$ tym coachem będzie chciał podjąć pracę rozwojową. 
(poziom psychologiczny). Większość z ustaleń zostaje przeniesiona do kontraktu prawnego, którego podpisanie przez strony wieńczy całość.

Rys. 2 przedstawia strukturę prowadzenia sesji, osadzoną na osi czasu. Nie odzwierciedla on rzeczywistego czasu, jaki coach poświęca na każdy z elementów, ponieważ jest to mocno zindywidualizowane. Pokazuje raczej kolejne elementy w strukturze. Ciemniejszym kolorem zostały wyróżnione kluczowe elementy procesu z punktu widzenia AT. Oba dotyczą kontraktu, ponieważ plan działania jest również pewną formą kontraktu. Tab. 1 zawiera dokładny opis każdego z etapów wraz z wybranymi narzędziami.

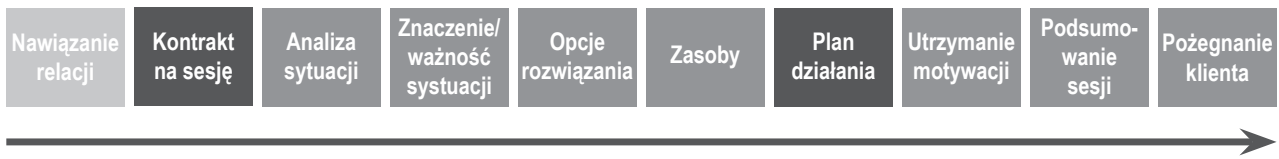

Rys. 2. Struktura sesji coachingowej.

Źródło: opracowanie własne.

Tab. 1. Struktura sesji coachingowej - charakterystyka etapów

\begin{tabular}{|c|c|}
\hline Etap procesu & Treść procesu oraz możliwe do zastosowania narzędzia \\
\hline Nawiązanie relacji & $\begin{array}{l}\text { Moment na wymianę znaków rozpoznania między klientem } \\
\text { a coachem. }\end{array}$ \\
\hline Kontrakt na sesję & $\begin{array}{l}\text { Obejmuje wszystkie poziomy kontraktu według Berne’a i Hay: } \\
\text { - proceduralny - czas trwania, } \\
\text { - profesjonalny - cel na sesję, określenie efektów, roli coacha, } \\
\text { - psychologiczny - np. omówienie ewentualnych obaw; uważność } \\
\text { na zaproszenia do gier. } \\
\text { Kontrakt na sesję jest zwykle poprzedzony krótkim opisem } \\
\text { sytuacji przez klienta. Coach powinien pamiętać, aby na tym etapie } \\
\text { wysłuchać wstępnej opowieści, ale nie pozwalając na } \\
\text { natychmiastowe przejście do analizy sytuacji i analizy możliwych } \\
\text { opcji. Należy dopilnować ustalenia kontraktu. Przykładowe } \\
\text { pytania: } \\
\text { 1. Co miałoby być efektem naszego dzisiejszego spotkania? } \\
\text { 2. Po czym poznasz, że osiągnąłeś swój cel? } \\
\text { 3. Co zmieni się w Tobie? }\end{array}$ \\
\hline Analiza sytuacji & $\begin{array}{l}\text { Odnosi się do analizy sytuacji, w której znalazł się klient. Główne } \\
\text { pytanie na tym etapie brzmi: jak wygląda sytuacja? De facto odnosi } \\
\text { się ono do tego, jak sytuację widzi klient, a niekoniecznie do tego, } \\
\text { jaka jest ona w rzeczywistości. }\end{array}$ \\
\hline
\end{tabular}




\begin{tabular}{|c|c|}
\hline $\begin{array}{l}\text { Znaczenie ważności } \\
\text { sytuacji }\end{array}$ & $\begin{array}{l}\text { Analiza tego elementu jest bardzo ważna, ponieważ pozwala } \\
\text { dotrzeć do motywacji klienta, systemu wartości. Przykładowe } \\
\text { pytania: } \\
\text { 1. Dlaczego to jest dla Ciebie takie ważne? } \\
\text { 2. Dlaczego akurat teraz? } \\
\text { 3. Jakie znaczenie ma dla Ciebie ta sytuacja? } \\
\text { 4. Co zyskasz, jeśli rozwiążesz tę sytuację? }\end{array}$ \\
\hline Opcje rozwiązania & $\begin{array}{l}\text { Na tym etapie zadaniem coacha jest pobudzenie kreatywności } \\
\text { coachee w generowaniu dostępnych opcji rozwiązania sytuacji. } \\
\text { Można w tym celu użyć dostępnych technik kreatywnych (jak np. } \\
\text { burza mózgów, strategia Disneya) lub pobudzić kreatywność } \\
\text { klienta za pomocą pytań. Przykładowe pytania: } \\
\text { 1. Co do tej pory już zrobiłeś? } \\
\text { 2. Czego do tej pory już próbowałeś? } \\
\text { 3. Gdyby wszystko było możliwe, to jakie dodatkowe opcje } \\
\text { mogłyby się tutaj pojawić? } \\
\text { 4. Co jeszcze? }\end{array}$ \\
\hline Zasoby & $\begin{array}{l}\text { Ten element procesu odnosi się głównie do zasobów i możliwości } \\
\text { po stronie coachee. Często nierozpoznanie na tym poziomie } \\
\text { przejawia się stwierdzeniem: „W sumie to nie mam na to wpływu” } \\
\text { albo „Nie umiem tego zrobić”. Ważne jest zatem, aby klient } \\
\text { odzyskał wpływ i znów poczuł się w pełni swojej „mocy”. } \\
\text { Ten obszar przeplata się z etapem wcześniejszym i go uzupełnia. } \\
\text { Odnosi się do zadawania pytań o zasoby klienta rozumiane jako } \\
\text { zasoby wewnętrzne, ale również zewnętrzne. Dokładna ich analiza } \\
\text { pozwala spojrzeć na proponowane rozwiązania z perspektywy } \\
\text { realnie dostępnych zasobów. Przykładowe pytania: } \\
\text { 1. Na co masz wpływ w tej sytuacji? } \\
\text { 2. Jak poradziłeś sobie w podobnej sytuacji? } \\
\text { 3. Biorąc pod uwagę dostępne zasoby, które z rozwiązań wydaje } \\
\text { się najbardziej realne? }\end{array}$ \\
\hline Plan działania & $\begin{array}{l}\text { Plan działania dotyczy konkretnych kroków podejmowanych przez } \\
\text { klienta po sesji. Przykładowe pytania: } \\
\text { 1. Co będzie pierwszą rzeczą, jaką zrobisz, aby osiągnąć swój cel? } \\
\text { 2. Jak zamierzasz to zrealizować? } \\
\text { 3. Jakie konkretne kroki podejmiesz w tej sytuacji? }\end{array}$ \\
\hline Utrzymanie motywacji & $\begin{array}{l}\text { Zazwyczaj klient w trakcie sesji jest bardzo zmotywowany. } \\
\text { Doświadczenie autorki pokazuje jednak, że nie zawsze } \\
\text { wypracowany plan działania jest wdrażany przez klienta. } \\
\text { Najczęściej sabotuje on w ten sposób własny sukces. Aby } \\
\text { zwiększyć prawdopodobieństwo działania, warto przeanalizować } \\
\text { możliwe opcje, które pozwolą utrzymać wysoką motywację. } \\
\text { Przykładowe pytania: } \\
\text { 1. Jak zamierzasz utrzymać motywację do działania? } \\
\text { 2. Co może Ci przeszkodzić we wdrożeniu Twojego planu w życie } \\
\text { (w Tobie, w środowisku)? } \\
\text { 3. Jak się przed tym zabezpieczysz? }\end{array}$ \\
\hline
\end{tabular}




\begin{tabular}{|l|l|}
\hline Podsumowanie sesji & $\begin{array}{l}\text { Podsumowanie sesji pozwala klientowi na poddanie krótkiej } \\
\text { refleksji tego, co wydarzyło się podczas spotkania. Pozwala na } \\
\text { określenie elementu, który był dla niego kluczowy. }\end{array}$ \\
\hline Pożegnanie klienta & $\begin{array}{l}\text { Ten element kończy sesję. Pożegnanie jest ważne ze względu na } \\
\text { wymianę znaków rozpoznania. }\end{array}$ \\
\hline
\end{tabular}

Źródło: opracowanie własne.

\section{ZAKOŃCZENIE}

Executive coaching różni się od pracy z innymi klientami coachingowymi taką tezę postawili w swoim artykule Scherer i Barnes (Czarkowska [red.] 2013, s. 201). Autorka niniejszego opracowania w pełni zgadza się z tym twierdzeniem. „Inność" polega szczególnie na tym, że trudno w przypadku pracy z liderami mówić o coachingu zadaniowym czy czysto behawioralnym. Coaching liderów to często coaching transformacyjny, który obejmuje zmianę nie tylko na poziomie zachowań, ale często też na poziomie postaw i wartości. Liderzy niosą na swoich barkach olbrzymi ciężar odpowiedzialności, ponieważ wyniki ich pracy dotykają nie tylko ich samych, ale przede wszystkim system, w którym pracują. W systemie tym zaś, uwikłani w relacje interpersonalne na różnych poziomach, muszą potrafić godzić różne interesy i cały czas pozostawać świadomymi tego, jak wielki impakt ich zachowania mają na innych. Dodatkowo, często samotni w swoich biurach, rzadko mogą liczyć na rzetelną i szczerą informację zwrotną. Na pewnym poziomie zarządzania trudno im nawet dzielić się swoimi wątpliwościami, ponieważ nie zawsze mają z kim.

Coaching liderów wymaga zatem zaangażowania zaawansowanej wiedzy psychologicznej ze strony coacha, zwłaszcza że praca z menedżerami jest wymagająca także pod kątem utrzymania i kontrolowania procesu sesji. Mogą się w niej pojawić: walka o władzę, zaproszenia do symbiozy czy gry psychologiczne z pozycji Prześladowcy, z którymi może być trudno poradzić sobie mało doświadczonemu oraz nieposiadającemu odpowiedniej wiedzy coachowi. Analiza Transakcyjna służy w tym obszarze wsparciem nie tylko przez dostarczanie pomocnych narzędzi do prowadzenia sesji, ale przede wszystkim w zakresie rozumienia psychologicznej natury relacji występujących w tym dynamicznym procesie transformacji. 


\section{BIBLIOGRAFIA}

Atkinson M., Chois R.T. (2009), Wewnętrzna dynamika coachingu, Warszawa: Wydawnictwo New Down.

Berne E. (1966), The Structure and Dynamics of Organisations and Groups, New York: Grove Press Inc.

Berne E. (2007), Dzień dobry i co dalej?, Poznań: Dom Wydawniczy Rebis.

Berne E. (2008), Transactional Analysis in Psychotherapy, A Condor Book Souvenir Press Ltd.

Berne E. (2012), W co graja ludzie?, Warszawa: Wydawnictwo Naukowe PWN.

Cassoni E. (2007), Parallel process in supervision and therapy: An opportunity for reciprocity, "Transactional Analysis Journal”, Vol. 37(2), DOI: https://doi.org/10.1177/036215370703700205.

Choy A. (1990), The winner's triangle, “Transactional Analysis Journal), Vol. 20(1), DOI: https://doi.org/10.1177/036215379002000105.

Czarkowska L. (red.) (2013), Leadership Coaching jako odpowiedź na wyzwania wspótczesnego świata, Warszawa: Wydawnictwo Poltex.

English F. (1975), The three-cornered contract, "Transactional Analysis Journal”, Vol. 5(4).

George B., Sims P., McLean A.N., Mayer D. (2007), Discovering your authentic leadership, "Harvard Business Review", Vol. 85(2).

Hay J. (2007), Reflective Practice and Supervision for Coaches, London: Open University Press.

Hay J. (2010), Analiza Transakcyjna dla trenerów, Kraków: Grupa Doradczo-Szkoleniowa Transmisja.

Hay J. (2012), Donkey Bridges for Developmental TA, Hartford: Sherwood Publishing.

James J. ( 1973), The game plan, “Transactional Analysis Journal”, Vol. 3(4).

Kahn W.A. (2012), The functions of dysfunction: Implications for organisational diagnosis and change, "American Psychological Association", Vol. 64(3).

Krausz R.R. (2005), Transactional executive coaching, "Transactional Analysis Journal”, Vol. 35(4), DOI: https://doi.org/10.1177/036215370503500414.

Kopaliński W. (1989), Stownik wyrazów obcych i zwrotów obcojęzycznych, wyd. 13, Warszawa: Wiedza.

Mellor K., Schiff E. (1975), Discounting, "Transactional Analysis Journal”, Vol. 5(3).

Micholt N. (1992), Psychological distance and group interventions, "Transactional Analysis Journal", Vol. 22(4), DOI: https://doi.org/10.1177/036215379202200406.

Newton T., Napper R. (2010), Transactional Analysis and coaching, [w:] E. Cox, T. Bachkirova, D. Clutterbuck, The Complete Handbook of Coaching, SAGE Publications.

Steiner C. (1990), Scripts People Live, New York: Grove Press.

Stewart I. (2000), Developing Transactional Analysis Counselling, SAGE Publications.

Stewart I. (2007), Transactional Analysis Counselling in Action, SAGE Publications.

Stewart I., Joines V. (2016), Analiza Transakcyjna dzisiaj, Poznań: Dom Wydawniczy Rebis.

Stokes J., Jolly R. (2010), Executive and leadership coaching, [w:] E. Cox, T. Bachkirova, D. Clutterbuck, The Complete Handbook of Coaching, SAGE Publications.

Watkins E.C. (2016), Reconsidering parallel process in psychotherapy supervision: On persimony, rival hypotheses, and alternate explanation, "American Psychological Association". 


\section{SUMMARY}

This article discussed the use of Transactional Analysis concept in executive coaching. The author focused on the basic principles of work with the client as well as selected tools in leading the executive coaching process. One of the main limitations of the Transactional Analysis theory is that it has no clear and structured methodology for coaching session. Thus, it can serve as a support for experienced coaches with, however, limited impact on the whole coaching society. In the last part of the article, the author proposed a model of coaching session structure in Transactional Analysis field, which was developed based on her professional practice in working with managers and organisations.

Keywords: executive coaching; Transactional Analysis; coaching in Transactional Analysis; tools in coaching; structure of coaching session 